\title{
Clinical presentation and management strategies for yolk sac tumor. A case series and review of the literature
}

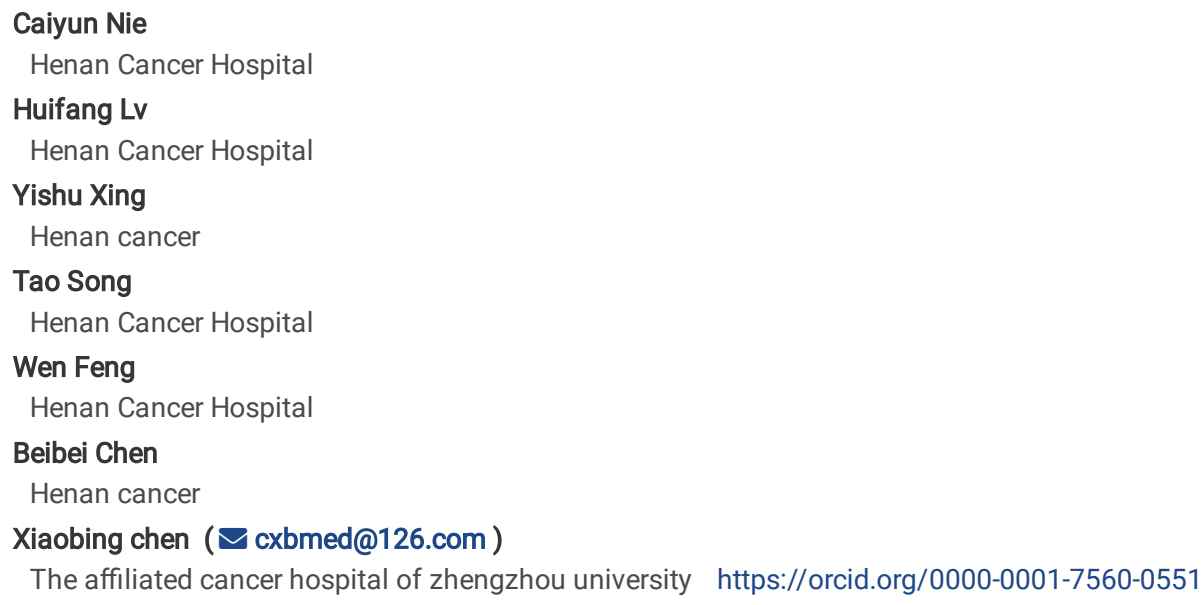

Research

Keywords: Yolk sac tumor, Clinicopathological features, Treatment, Prognosis

Posted Date: March 4th, 2020

DOI: https://doi.org/10.21203/rs.3.rs-16026/v1

License: (c) (1) This work is licensed under a Creative Commons Attribution 4.0 International License. Read Full License 


\section{Abstract}

Background: Yolk sac tumor (YST), also known as endodermal sinus tumor, is a highly malignant germ cell-derived tumor. As a rare disease, the diagnosis, prognostic factors, and optimal management of yolk sac tumor are difficult. The present study aims to investigate the clinicopathological features and optimal management strategies of yolk sac tumor.

Results: We retrospectively investigated seventeen patients with yolk sac tumor in our institute between January 2010 to December 2019 . The median age of the study population was 24 years (range $6-50$ years). Most cases were female (11/17, 64.7\%). Among the seventeen cases of YSTs, 8 cases were ovarian YSTs, 3 cases were mediastinum YSTs, 2 cases were testis YSTs. 94.1\% patients had a markedly raised AFP. Surgery and chemotherapy were the main treatment methods for YST and improved the prognosis of patients.

Conclusions: YST is a highly malignant and rare germ cell tumor, ovarian YST is the most common type. Early diagnosis and reasonable treatment can improve the prognosis of YST. These cases highlight the tumor's characteristics. As more experience is gathered with this rare malignant tumor, the more likely we are to cure this disease.

\section{Background}

Yolk sac tumor (YST), also called endodermal sinus tumor, is a germ cell-derived tumor with a high degree of malignancy. Yolk sac tumors mainly occur in the gonads and can also occur on the midline path of germ cells migrating from the yolk sac, such as the anterior mediastinum, the tail of the iliac crest, the abdominal cavity, the retroperitoneum, the vagina, the vulva and the pineal gland[1].

Ovarian yolk sac tumors are the most common yolk sac tumors, accounting for $22 \%$ of malignant germ cell tumors and $1 \%$ of ovarian malignant tumors[2]. The degree of malignancy is extremely high, since the advent of effective combination chemotherapy, from the VAC program in the 1970s, and to the introduction of the PVB and PEB programs in the 1980s, the cure rate of ovarian yolk sac tumor has been continuously improved.

Nevertheless, the disease is still poorly understood clinically, early diagnosis is difficult, and when the symptoms appear, the tumor is large or has invaded adjacent tissues or organs. Especially for yolk sac tumors elsewhere, we know very little about their biological behavior and optimal treatment strategy.

In the present study, we retrospectively studied seventeen cases of YST from January 2010 to December 2019 treated in Henan Cancer Hospital, in an attempt to determine the common clinical features, prognosis and management strategies of this rare entity.

\section{Results}

\section{Patient and tumor characteristics}

A total of seventeen patients were analyzed retrospectively. None of the patients had a previous history of malignant disease. The median age of the study population was 24 years (range 6-50 years). Most cases were female (11/17, 64.7\%). Among the seventeen cases of YSTs, 8 cases were ovarian YSTs, 3 cases were mediastinum YSTs, 2 cases were testis YSTs. 94.1\% patients had a markedly raised AFP. Clinicopathological features of patients were showed in Table 1. Some typical cases are described below. Clinicopathological features, treatment and follow up of the patients are discussed and summarized in Table 2 . 
Table 1

Clinicopathological features of patients.

\begin{tabular}{|c|c|c|}
\hline & No. & $\%$ \\
\hline \multicolumn{3}{|c|}{ Age at initial treatment } \\
\hline \multicolumn{3}{|c|}{ Median 24 years } \\
\hline \multicolumn{3}{|c|}{ Range $6-50$ years } \\
\hline \multicolumn{3}{|l|}{ Gender } \\
\hline Male & 6 & $35.3 \%$ \\
\hline Female & 11 & $64.7 \%$ \\
\hline \multicolumn{3}{|l|}{ Primary site } \\
\hline Ovary & 8 & $47.1 \%$ \\
\hline Mediastinum & 3 & $17.6 \%$ \\
\hline Testis & 2 & $11.8 \%$ \\
\hline Other sites & 4 & $23.5 \%$ \\
\hline \multicolumn{3}{|l|}{ Pathology } \\
\hline Pure YST & 12 & $70.6 \%$ \\
\hline Mixed tumor & 5 & $29.4 \%$ \\
\hline \multicolumn{3}{|l|}{ AFP } \\
\hline Raised & 16 & $94.1 \%$ \\
\hline Normal & 1 & $5.9 \%$ \\
\hline \multicolumn{3}{|c|}{ YST, Yolk sac tumor; AFP, Alpha fetoprotein. } \\
\hline
\end{tabular}


Table 2

Clinicopathological features, treatment and follow up of patients.

\begin{tabular}{|c|c|c|c|c|c|c|c|c|c|}
\hline $\begin{array}{l}\text { Case } \\
\text { identity }\end{array}$ & Gender & $\begin{array}{l}\text { Age at } \\
\text { diagnosis }\end{array}$ & $\begin{array}{l}\text { Symptoms } \\
\text { and signs }\end{array}$ & Tumor site & $\begin{array}{l}\text { Imaging } \\
\text { findings }\end{array}$ & $\begin{array}{l}\text { Pathological } \\
\text { type }\end{array}$ & Immunohistochemistry & Treatment & Follow up \\
\hline 1 & $\mathrm{~F}$ & 6 & $\begin{array}{l}\text { Abdominal } \\
\text { distension }\end{array}$ & Ovary & $\begin{array}{l}\text { A huge } \\
\text { mixed } \\
\text { density } \\
\text { mass of } \\
\text { pelvis }\end{array}$ & $\begin{array}{l}\text { YST plus } \\
\text { teratoma }\end{array}$ & AFP+, SALL4+ & $\begin{array}{l}\text { Surgery plus } \\
\text { PEB } \\
\text { chemotherapy }\end{array}$ & $\begin{array}{l}\text { Alive, } \\
\text { DFS } \\
63 \mathrm{~m}\end{array}$ \\
\hline 2 & $\mathrm{~F}$ & 23 & $\begin{array}{l}\text { Abdominal } \\
\text { distension, } \\
\text { pelvic } \\
\text { mass and } \\
\text { ascites }\end{array}$ & Ovary & $\begin{array}{l}\text { Pelvic } \\
\text { mass, } \\
\text { metastatic } \\
\text { nodules, } \\
\text { peritoneal } \\
\text { effusion }\end{array}$ & YST & $\begin{array}{l}\text { AFP+, SALL4+, ki-67 + } \\
5 \%\end{array}$ & $\begin{array}{l}\text { Surgery plus } \\
\text { PEB } \\
\text { chemotherapy }\end{array}$ & $\begin{array}{l}\text { Alive, } \\
\text { DFS } \\
75 \mathrm{~m}\end{array}$ \\
\hline 3 & $\mathrm{~F}$ & 31 & Negative & Ovary & $\begin{array}{l}\text { Ovarian } \\
\text { mass }\end{array}$ & YST & $\begin{array}{l}\text { AFP+, SALL4+, ki-67 + } \\
35 \%\end{array}$ & $\begin{array}{l}\text { Surgery plus } \\
\text { PEB } \\
\text { chemotherapy }\end{array}$ & $\begin{array}{l}\text { Alive, } \\
\text { DFS } \\
58 \mathrm{~m}\end{array}$ \\
\hline 4 & $\mathrm{~F}$ & 50 & $\begin{array}{l}\text { Pelvic } \\
\text { mass }\end{array}$ & Ovary & $\begin{array}{l}\text { Pelvic } \\
\text { cystic solid } \\
\text { mass }\end{array}$ & YST & AFP+, SALL4+ & $\begin{array}{l}\text { Surgery plus } \\
\text { PEB } \\
\text { chemotherapy }\end{array}$ & $\begin{array}{l}\text { Alive, } \\
\text { DFS } 5 \mathrm{~m}\end{array}$ \\
\hline 5 & $\mathrm{~F}$ & 31 & $\begin{array}{l}\text { Left } \\
\text { lumbago }\end{array}$ & Kidney & $\begin{array}{l}\text { Cystic } \\
\text { mass of } \\
\text { left kidney }\end{array}$ & $\begin{array}{l}\text { Mixed germ } \\
\text { cell tumor } \\
\text { (mainly } \\
\text { YST) }\end{array}$ & $\begin{array}{l}\text { AFP+, SALL4+, ki-67+ } \\
40 \%\end{array}$ & $\begin{array}{l}\text { Surgery plus TP } \\
\text { chemotherapy }\end{array}$ & $\begin{array}{l}\text { Alive, in } \\
\text { treatment }\end{array}$ \\
\hline 6 & M & 23 & Cough & Mediastinum & $\begin{array}{l}\text { Mediastinal } \\
\text { mass, } \\
\text { pleura } \\
\text { nodules }\end{array}$ & YST & $\begin{array}{l}\text { AFP+, SALL4+, ki-67+ } \\
70 \%\end{array}$ & $\begin{array}{l}\text { Surgery plus } \\
\text { PEB } \\
\text { chemotherapy }\end{array}$ & $\begin{array}{l}\text { Alive, } \\
\text { DFS } \\
21 \mathrm{~m}\end{array}$ \\
\hline 7 & M & 24 & $\begin{array}{l}\text { Dry cough, } \\
\text { fever }\end{array}$ & Mediastinum & $\begin{array}{l}\text { Mediastinal } \\
\text { mass, } \\
\text { lymph } \\
\text { nodes, } \\
\text { pleural } \\
\text { effusion }\end{array}$ & YST & $\begin{array}{l}\text { AFP+, SALL4+, ki-67+ } \\
70 \%\end{array}$ & Palliative care & $\begin{array}{l}\text { Died } 2 \\
\text { months } \\
\text { after } \\
\text { diagnosis }\end{array}$ \\
\hline 8 & M & 28 & $\begin{array}{l}\text { Back pain, } \\
\text { intermittent } \\
\text { fever, night } \\
\text { sweats }\end{array}$ & Testicle & $\begin{array}{l}\text { Testis } \\
\text { mass }\end{array}$ & YST & $\begin{array}{l}\text { AFP+, SALL4+, ki-67+ } \\
50 \%\end{array}$ & $\begin{array}{l}\text { Surgery, } \\
\text { chemotherapy, } \\
\text { immunotherapy }\end{array}$ & $\begin{array}{l}\text { Relapse } 6 \\
\text { months } \\
\text { after } \\
\text { diagnosis }\end{array}$ \\
\hline
\end{tabular}

\section{Case 1}

A 6-year-old girl was admitted to the hospital mainly after "left ovarian tumor ablation". The patient had unintentionally found abdominal distension more than 3 months ago, and then went to the local hospital for "left ovarian tumor ablation". Postoperative pathology showed immature teratoma of left ovary. No further treatment was performed, and a review of ultrasound after 3 months showed that there was a solid placeholder in the pelvic cavity. Physical examination can touch a solid mass of about $50 * 30 \mathrm{~mm}$ in size in the muscle layer between the lower abdominal wall, and a solid mass of about $15 \mathrm{~cm}$ in diameter in the right attachment area, which has an irregular shape, poor movement, and no tenderness. Imaging examination of CT suggests a huge mixed density mass of pelvis. Then the patient underwent left appendix plus appendectomy plus pelvic metastases resection, histological examination showed mixed germ cell tumor, yolk tumor and teratoma components can be seen. After surgery, the patient subsequently underwent six cycles of PEB combination chemotherapy. The patient was diagnosed and treated in 2014 and was alive without recurrence to now.

\section{Case 2}

A 23-year-old woman with no significant past medical history was admitted to the hospital presented with a 7-days history of abdominal distension and found pelvic mass and ascites for 2 days. Physical examination can touch a solid mass of about 18 * $12 \mathrm{~cm}$ in size in the right accessory area. Imaging examination of CT suggests a huge mass in the right lower abdominal pelvic cavity, multiple metastatic nodules in ovarian and peritoneal, and massive peritoneal effusion (Fig. 1A). Simultaneously the patient had a markedly raised AFP ( $>1210 \mathrm{ng} / \mathrm{mL}$ ). In order to confirm the diagnosis, the patient received laparoscopy plus pelvic tumor biopsy, after placement of the microscope, the pelvic peritoneal cavity had a light red bloody ascites of about $3000 \mathrm{ml}$. There were multiple white nodules on the peritoneal surface of the pelvic peritoneum, and a tumor of about $18^{\star} 15^{\star} 12 \mathrm{~cm}$ was seen on the right appendix. Biopsy pathology confirmed ovarian YST. The patient's clinical stage is too late to undergo surgery, two cycles of PEB combination preoperative chemotherapy was conducted. After 2 cycles, the original right lower abdominal pelvic mass was significantly smaller than before, the omentum was not thickened, and the 
peritoneal fluid disappeared. AFP declined to $38.03 \mathrm{ng} / \mathrm{mL}$. Then, the patient underwent right ovariectomy and 4 cycles of adjuvant PEB combination chemotherapy. The patient was diagnosed and treated in 2013 and was alive without recurrence to now (Fig. 1B).

\section{Case 3}

A 31-year-old woman was admitted to the hospital presented with a 2-days history of ovarian mass. The patient is special, because she was already 32 weeks pregnant. During the previous pregnancy physical examination, no abnormalities were found. Until 2 days ago, an ultrasound examination during pregnancy revealed an ovarian mass. Ultrasound examination shows that the ovarian mass is more likely to be malignant. Simultaneously the patient had a markedly raised AFP (>1210 ng/mL). The patient refused surgery because she was only 32 weeks pregnant. After 4 weeks, the patient underwent concurrent cesarean section and left appendectomy. The child is healthy. Postoperative pathology: ovarian YST, IHC: inhibin (-), CD99(+), CD117(+), PLAP+/-, AFP (+), CKmix (+), Ki-67 > 35\%, SALL4 +, CK7(-). After surgery, the patient subsequently underwent six cycles of PEB combination chemotherapy. During treatment, AFP decreased from $>1210 \mathrm{ng} / \mathrm{mL}$ to $26.44 \mathrm{~g} / \mathrm{mL}$. After the treatment, the patient was regularly reviewed in our hospital, and since 2015 , she was in stable condition with no signs of recurrence.

\section{Case 4}

A 50-year-old woman was admitted to the hospital presented with a 10-days history of pelvic mass. This is a post-menopausal woman. The patient underwent an ultrasound examination at the local hospital 7 years ago, which revealed a pelvic mass. There was no discomfort symptom such as abdominal pain and bloating. She had not undergone treatment and had not been reviewed regularly. Until 10 days ago, the patient had lower abdominal pain without obvious incentives. Ultrasound examination showed that a $144 \times 95 \mathrm{~mm}$ cystic solid mass was seen on the right side of the uterus in the pelvis, with clear borders and uneven internal echo, several cystic echoes were seen. Then the patient underwent abdominal exploratory surgery, during the operation, a large cystic solid mass was found on the left side of the pelvic cavity, which originated from the left ovary. Left appendectomy was performed. Postoperative pathology showed left ovarian YST. After surgery, the patient subsequently underwent 4 cycles of PEB combination chemotherapy and 2 cycles of VP-16 chemotherapy. During treatment, AFP decreased from $4496 \mathrm{ng} / \mathrm{mL}$ to $3.42 \mathrm{ng} / \mathrm{mL}$. In November 2019 , the patient completed the last cycle of chemotherapy and is currently in good condition.

\section{Case 5}

A 31-year-old woman was admitted to the hospital presented with a 5-days history of left lumbago. The patient's previous medical history was reviewed, 8 years ago, she went to the hospital for a gynecological disease. Ultrasound examination revealed a left kidney cyst but was not treated. Until 5 days ago, the patient had left lumbago. Imaging examination of CT suggests a huge cystic mass of left kidney of about 67 * $64 \mathrm{~mm}$ in size, a retroperitoneal cystic mass, $69 * 57 \mathrm{~mm}$ in size. Then the patient underwent left nephrectomy plus left retroperitoneal mass resection plus abdominal adhesion release surgery. Postoperative pathology showed left kidney mixed germ cell tumor (mainly composed of YST). After surgery, the patient subsequently underwent 5 cycles of docetaxel + nedaplatin combination chemotherapy. Unlike the previous cases, the patient's AFP level has been within the normal range. Currently, the patient was preparing for the sixth cycle of chemotherapy.

\section{Case 6}

A 23-year-old man was admitted to the hospital presented with a 1-month history of cough. More than 1 month ago, the patient developed cough without accompanying symptoms such as asthma, chest tightness, chest pain, hoarseness, cough, and dyspnea. Anti-inflammatory and cold medicine treatments were not effective, and the symptoms continued. CT examination at the local hospital showed that irregular masses were seen in the anterior mediastinum. Imaging examination of CT suggests an irregular anterior mediastinal mass, $101 * 65 \mathrm{~mm}$ in size, and slightly enlarged lymph nodes in the mediastinum by $10 \mathrm{~mm}$ in diameter (Fig. 2A). AFP level is $33.33 \mathrm{ng} / \mathrm{mL}$. Then the patient underwent resection of right anterior mediastinal mass + partial resection of right middle and upper lobe surgery. Postoperative pathology showed: (right anterior mediastinum) morphology and immunohistochemistry were consistent with YST. An additional mediastinal lymph node is sent 0/1. IHC: CK7-, TTF-1-, NapsinA-, CD30-, CD117 +, PLAP +, ki-67 + 70\%, AFP +, SALL4 +, CK8/18 +, VIm-, CK + . Patient did not receive chemotherapy after surgery, 3 months later, CT showed multiple nodules in bilateral pleura, considering the possibility of metastasis, AFP level increased from 33.33 to $37.58 \mathrm{ng} / \mathrm{mL}$ (Fig. 2B). The patient underwent 4 cycles of PEB combination chemotherapy, CT evaluation of clinical efficacy as CR after chemotherapy. AFP decreased from $37.58 \mathrm{ng} / \mathrm{mL}$ to $1.51 \mathrm{ng} / \mathrm{mL}$. The treatment was completed in May 2018 and the condition is stable now (Fig. 2C).

\section{Case 7}

A 24-year-old man was admitted to the hospital presented with half a month history of dry cough. Half a month ago, the patient developed a dry cough without chest discomfort, chest pain, and other discomforts. He developed low fever at night, which can reach $38^{\circ} \mathrm{C}$ at high temperatures. Later, the patient's symptoms gradually worsened, and chest discomfort, asthma and other discomforts appeared. Chest CT revealed a huge mass in the anterior mediastinum of the chest, considering lung cancer. "Paclitaxel + carboplatin" was given for 1 cycle of chemotherapy. After coming to our hospital, a biopsy of the mediastinal mass was performed, and the pathology proved to be YST. CT showed an anterior mediastinal mass of $112^{\star} 72$ mm, multiple lymph nodes in the left clavicle and mediastinum, pleural effusion, multiple nodules in the lungs and liver, and metastases were possible, right brain metastasis with peripheral

Page 5/9 
edema. Patients are generally in poor condition and cannot tolerate chemotherapy. Mediastinal masses and metastatic lesions progress rapidly in a month, followed by cerebral hemorrhage.

\section{Case 8}

A 28-year-old man was admitted to the hospital presented with half a month history of right testicle tumor. The patient had an enlarged right testicle 2 months ago, and later had back pain, intermittent fever, up to $39^{\circ} \mathrm{C}$, night sweats, and MRI showed that the right testicle increased in volume with abnormal signal occupying, $29 * 18 * 34 \mathrm{~mm}$ in size. CT suggests multiple metastases in both lungs. Then the patient underwent right testis and epididymis resection surgery, postoperative pathology showed: right testis YST. After surgery, the patient subsequently underwent 4 cycles of PEB combination chemotherapy. After chemotherapy, CT shows shrinkage of bilateral lung metastases, but the patient did not undergo maintenance chemotherapy. After half a year, both lung nodules increased compared to the previous, and multiple brain metastases appeared at the same time. Later, the patient received Keytruda (Pembrolizumab) immunotherapy, liposomal doxorubicin, paclitaxel chemotherapy, cranial radiotherapy, and local interventional therapy. Despite multiple treatments were given, the treatment is not effective.

\section{Discussion}

YST, also known as endodermal sinus tumor, is a highly malignant and rare germ cell tumor, which was proposed by Teilum G in 1959[3]. Ovarian YST is the most common type[4], 10-15\% of cases may arise from various midline extragonadal sites. Between January 2010 to December 2019 , only twenty-four cases of YSTs were diagnosed in our institute. It is because of the low incidence of YST, our understanding of the biological behavior of YST is not very well. In case 7, the patient was first diagnosed as lung cancer. So far, there is no large-scale review article in the database to discuss the biological behavior, treatment strategies, and prognosis of YST. Our present study retrospectively analyzed through a series of typical cases, in an attempt to determine the common clinical features, prognosis and management strategies of this rare entity.

Early diagnosis is of great significance for improving the treatment level of YSTs, but unfortunately, the clinical manifestations of YSTs lack specificity, and early stage patients generally have no obvious symptoms of discomfort. The main clinical symptom of YST is a huge mass, which is the same for YST of ovary and other sites[5]. In our present study, most patients present with massive pelvic, abdominal or mediastinal masses. Mass compression, invasion of surrounding tissues, produces a series of non-specific symptoms, such as abdominal pain, bloating, abdominal mass, cough and other local symptoms. Patients generally have no systemic manifestations, and fever may appear in some cases, such as in case 7 and case 8 . If the tumor has distant metastases, there will be corresponding systemic manifestations of organ involvement. Lack of specific symptoms makes early diagnosis of YST difficult. Some cases have distant metastases at the time of diagnosis, such as in case 7 and case 8.

The cause of YST is still unknown, and traditional tumor risk factors, such as smoking, drinking, family history of the tumor, were not found in the above cases. In case 3, the patient had YST with concurrent pregnancy,during the previous pregnancy physical examination, no abnormalities were found, but at 32 weeks of pregnancy, the lesion was suddenly found. Whether pregnancy is the risk cause of YST is unclear. In general, the age of onset of YST is relatively young, the median age at the time of diagnosis of YST is 18 in the literature[6]. In case 1 of this present study, the youngest case was only 6 years old. Previous literature reports that postmenopausal women may also develop YSTs[7]. In case 4, the patient was a postmenopausal woman. The onset time of YST is unknown, when most patients are diagnosed, the tumor is already large. In case 4, the patient had found a pelvic tumor 7 years ago, in case 5 , ultrasound examination revealed a left kidney cyst 8 years ago but was not treated. YST onset time may be relatively long, and regular physical examination is especially important for early detection of tumor.

Ultrasound, CT and MRI are the main imaging diagnosis methods of YST. YST imaging findings are lack of specificity. In the imaging examination, the YST has a variety of imaging manifestations. The inside of the lesion may be solid or mixed with cysts, and there may be bleeding in the cysts. Due to the abundance of tumor blood vessels, the solid components of the enhanced scan showed obvious uneven enhancement, and the delay period continued to strengthen. The characteristic manifestation of the disease was both cystic change and obvious enhancement[8-10]. A significant increase in AFP is a characteristic manifestation of the disease. After surgery and chemotherapy, a significant decrease in AFP indicates chemotherapy response and a good treatment effect, and elevation of AFP may indicate relapse or progression of disease. However, in case 5, the patient's AFP level has been within the normal range. Therefore, AFP levels may be normal in some patients.

Pathological diagnosis is the gold standard for diagnosis of YST, most cases were histologically diagnosed with YST after surgery. In case 7, imaging examinations showed multiple metastases, so a biopsy of the mediastinal mass was performed. Pathological diagnosis under light microscopy may not be sufficient, and in most cases require immunohistochemical examination to confirm the diagnosis[11]. Immunohistochemical staining of AFP is valuable for the histologic diagnosis of YST, newer markers for YST including glypican-3 and SALL-like protein 4 (SALL4) may be useful in the identification of the YST component histologically[12]. AFP and SALL4 were routinely tested and positive in above cases. The YST can be pure or mixed with other germ-cell or epithelial tumors, including endometrioid adenocarcinoma, embryonal carcinoma and so on[13,14]. Some cases in the present study were mixed germ cell tumors, partly yolk sac tumor and partly immature teratoma. Mixed germ cell tumor (mainly composed of yolk sac tumor) was diagnosed in case 5 .

Surgery and chemotherapy are the main treatment methods for YST. The ideal treatment mode of YST has been under exploration. The initial treatment method for YST of ovary is whole uterus plus double appendectomy and postoperative chemotherapy with a single alkylating agent, but the prognosis is still poor. Combined chemotherapy significantly improves the prognosis of YST, which also makes it possible to reduce the extent of surgery[15, 16]. Local extended resection becomes the main surgical method in our present case series. Platinum-based combination chemotherapy regimen significantly reduces the risk of postoperative recurrence and improves patient's prognosis[17, 18]. Previous literature reports that among cisplatin-including regimens, $\mathrm{PEB}$ is more 
effective than others[19]. Similar to previous reports, a chemotherapeutic regimen comprising taxanes and VP16 was also utilized in our cases[20]. In case 6, the patient did not receive any adjuvant chemotherapy and soon relapsed. For advanced cases, rescue and neoadjuvant chemotherapy is still an important treatment manner[21]. Previous literature reports that the recommended course of PEB chemotherapy is 4 cycles. In this study, most patients received $4-6$ cycles of chemotherapy[5]. The optimal number of courses still needs to be explored. Whether immunotherapy is feasible still needs to be explored, such as case 8 who received PD1 immunotherapy after recurrence.

YST is a highly malignant tumor, but it can still obtain satisfactory prognosis if treated properly. Prognosis of PEB-treated YST were analyzed in two studies including 84 and 32 cases, with the five-year survival rates were $75-100 \%$ at Stage I and $63-75 \%$ at Stages II-IV[22]. Stage[17], residual tumor[17, 18, 23], ascites[17, 23], cisplatin containing chemotherapy in advanced cases[24], PEB therapy[22] and AFP decline rate [22] are the reported prognostic factors of YST to date in literatures. In our present study, the prognosis was good in most cases. Previous literature reports that the most common metastatic sites of YSTs are the lung and liver, once distant metastasis occurs, the disease progresses rapidly with a poor prognosis.

\section{Conclusions}

YST is a highly malignant and rare germ cell tumor, ovarian YST is the most common type. Surgery and chemotherapy are the main treatment methods for YST. Early diagnosis and reasonable treatment can improve the prognosis of YST. As more experience is gathered with this rare malignant tumor, the more likely we are to cure this disease.

\section{Methods}

\section{Study setting and patients}

Between January 2010 to December 2019, seventeen cases of YST were diagnosed and treated in Henan Cancer hospital with complete information. Inclusion criteria were pathological diagnosed cases of Yolk sac tumor, with complete clinical case data. In the seventeen cases of yolk sac tumors, three patients were histologically diagnosed with yolk sac tumor by core needle biopsy, then underwent extended resection and/or platinum-based chemotherapy. The other cases were histologically diagnosed with yolk sac tumor after surgery, and then underwent chemotherapy. We retrospectively reviewed the clinicopathological characteristic, treatment modalities and prognosis of these cases from medical records.

\section{Declarations}

Funding: This work was supported by the National Natural Science Foundation of China (No. 81472714).

Acknowledgements: Authors would like to acknowledge the medical record room and follow-up team of the Affiliated Cancer Hospital of Zhengzhou University.

Availability of data and materials: The datasets used and/or analyzed during the current study are available from the corresponding author on reasonable request.

Ethics approval and consent to participate: This study was carried out in accordance with the ethical guidelines of the 1975 Declaration of Helsinki and was approved by the ethics committee of the Affiliated Cancer Hospital of Zhengzhou University. Written informed consent was obtained from every patient for the use of the medical records for research purposes.

Consent for publication: Not applicable.

Competing Interests: The authors have declared that no competing interests exist.

Author Contributions: Conceptualization: Caiyun Nie, Xiaobing Chen. Retrieve data: Yishu Xing, Tao Song, Wen Feng, Beibei Chen. Formal analysis: Caiyun Nie, Huifang Lv, Xiaobing Chen. Funding acquisition: Xiaobing Chen. Writing original draft: Caiyun Nie, Xiaobing Chen. Writing - review \& editing: Caiyun Nie, Xiaobing Chen.

\section{References}

1. Gupta R, Mathur SR, Arora VK, Sharma SG. Cytologic features of extragonadal germ cell tumors: a study of 88 cases with aspiration cytology. Cancer. 2008;114(6):504-11. doi:10.1002/cncr.23983.

2. Goyal LD, Kaur B, Badyal RK. Malignant Mixed Germ Cell Tumors of the Ovary: A Series of Rare Cases. J Reprod Infertil. 2019;20(4):231-6.

3. Teilum G. Endodermal sinus tumors of the ovary and testis. Comparative morphogenesis of the so-called mesoephroma ovarii (Schiller) and extraembryonic (yolk sac-allantoic) structures of the rat's placenta. Cancer. 1959;12:1092-105. doi:10.1002/1097-0142(195911/12)12:6<1092::aidcncr2820120606>3.0.c0;2-v.

4. Kurman RJ, Norris HJ. Embryonal carcinoma of the ovary: a clinicopathologic entity distinct from endodermal sinus tumor resembling embryonal carcinoma of the adult testis. Cancer. 1976;38(6):2420-33. doi:10.1002/1097-0142(197612)38:6<2420::aid-cncr2820380630>3.0.c0;2-2.

5. Dallenbach P, Bonnefoi H, Pelte MF, Vlastos G. Yolk sac tumours of the ovary: an update. Eur J Surg Oncol. 2006;32(10):1063-75. doi:10.1016/j.ejso.2006.07.010. 
6. Li H, Xie Y, Shen Y. Ovarian endometrioid adenocarcinoma a with yolk sac tumor in a 41-year-old woman: a case report. Int J Clin Exp Pathol. 2019;12(9):3549-54.

7. Wang Y, Yang J, Yu M, Cao D, Zhang Y, Zong X et al. Ovarian yolk sac tumor in postmenopausal females: A case series and a literature review. Medicine (Baltimore). 2018;97(33):e11838. doi:10.1097/MD.0000000000011838.

8. Li YK, Zheng Y, Lin JB, Xu GX, Cai AQ, Zhou XG et al. CT imaging of ovarian yolk sac tumor with emphasis on differential diagnosis. Sci Rep. 2015;5:11000. doi:10.1038/srep11000.

9. Lin S, Li X, Sun C, Feng S, Peng Z, Huang S et al. CT findings of intrarenal yolk sac tumor with tumor thrombus extending into the inferior vena cava: a case report. Korean J Radiol. 2014;15(5):641-5. doi:10.3348/kjr.2014.15.5.641.

10. Choi HJ, Moon MH, Kim SH, Cho JY, Jung DC, Hong SR. Yolk sac tumor of the ovary: CT findings. Abdom Imaging. 2008;33(6):736-9. doi:10.1007/s00261-007-9355-5.

11. Mei K, Liu A, Allan RW, Wang P, Lane Z, Abel TW et al. Diagnostic utility of SALL4 in primary germ cell tumors of the central nervous system: a study of 77 cases. Mod Pathol. 2009;22(12):1628-36. doi:10.1038/modpathol.2009.148.

12. Cao D, Guo S, Allan RW, Molberg KH, Peng Y. SALL4 is a novel sensitive and specific marker of ovarian primitive germ cell tumors and is particularly useful in distinguishing yolk sac tumor from clear cell carcinoma. Am J Surg Pathol. 2009;33(6):894-904. doi:10.1097/PAS.0b013e318198177d.

13. Lopez JM, Malpica A, Deavers MT, Ayala AG. Ovarian yolk sac tumor associated with endometrioid carcinoma and mucinous cystadenoma of the ovary. Ann Diagn Pathol. 2003;7(5):300-5. doi:10.1016/s1092-9134(03)00081-9.

14. Taranto P, Carvalho FM, Roithmann S, Maluf FC. Ovarian yolk sac tumor coexisting with epithelial ovarian cancer: An aggressive rare entity. Gynecol Oncol Rep. 2017;22:37-9. doi:10.1016/j.gore.2017.09.004.

15. Solheim O, Gershenson DM, Trope CG, Rokkones E, Sun CC, Weedon-Fekjaer H et al. Prognostic factors in malignant ovarian germ cell tumours (The Surveillance, Epidemiology and End Results experience 1978-2010). Eur J Cancer. 2014;50(11):1942-50. doi:10.1016/j.ejca.2014.03.288.

16. Liu B, Lin G, Liu J, Liu H, Shang X, Li J. Primary mediastinal yolk sac tumor treated with platinum-based chemotherapy and extended resection: Report of seven cases. Thorac Cancer. 2018;9(4):491-4. doi:10.1111/1759-7714.12591.

17. Kawai M, Kano T, Furuhashi Y, Mizuno K, Nakashima N, Hattori SE et al. Prognostic factors in yolk sac tumors of the ovary. A clinicopathologic analysis of 29 cases. Cancer. 1991;67(1):184-92. doi:10.1002/1097-0142(19910101)67:1<184::aid-cncr2820670131>3.0.c0;2-c.

18. Nawa A, Obata N, Kikkawa F, Kawai M, Nagasaka T, Goto S et al. Prognostic factors of patients with yolk sac tumors of the ovary. Am J Obstet Gynecol. 2001;184(6):1182-8. doi:10.1067/mob.2001.113323.

19. Cicin I, Saip P, Guney N, Eralp Y, Ayan I, Kebudi R et al. Yolk sac tumours of the ovary: evaluation of clinicopathological features and prognostic factors. Eur J Obstet Gynecol Reprod Biol. 2009;146(2):210-4. doi:10.1016/j.ejogrb.2009.02.052.

20. Sakaguchi M, Maebayashi T, Aizawa T, Ishibashi N, Fukushima S, Saito T. Successful radiotherapy in postoperative recurrence of a primary mediastinal yolk sac tumor: A case report. Thorac Cancer. 2016;7(3):358-62. doi:10.1111/1759-7714.12302.

21. Talukdar S, Kumar S, Bhatla N, Mathur S, Thulkar S, Kumar L. Neo-adjuvant chemotherapy in the treatment of advanced malignant germ cell tumors of ovary. Gynecol Oncol. 2014;132(1):28-32. doi:10.1016/j.ygyno.2013.10.009.

22. de La Motte Rouge T, Pautier P, Rey A, Duvillard P, Kerbrat P, Troalen F et al. Prognostic factors in women treated for ovarian yolk sac tumour: a retrospective analysis of 84 cases. Eur J Cancer. 2011;47(2):175-82. doi:10.1016/j.ejca.2010.08.012.

23. Umezu T, Kajiyama H, Terauchi M, Shibata K, Ino K, Nawa A et al. Long-term outcome and prognostic factors for yolk sac tumor of the ovary. Nagoya J Med Sci. 2008;70(1-2):29-34.

24. Kojimahara T, Nakahara K, Takano T, Yaegashi N, Nishiyama H, Fujimori K et al. Yolk sac tumor of the ovary: a retrospective multicenter study of 33 Japanese women by Tohoku Gynecologic Cancer Unit (TGCU). Tohoku J Exp Med. 2013;230(4):211-7. doi:10.1620/tjem.230.211.

\section{Figures}




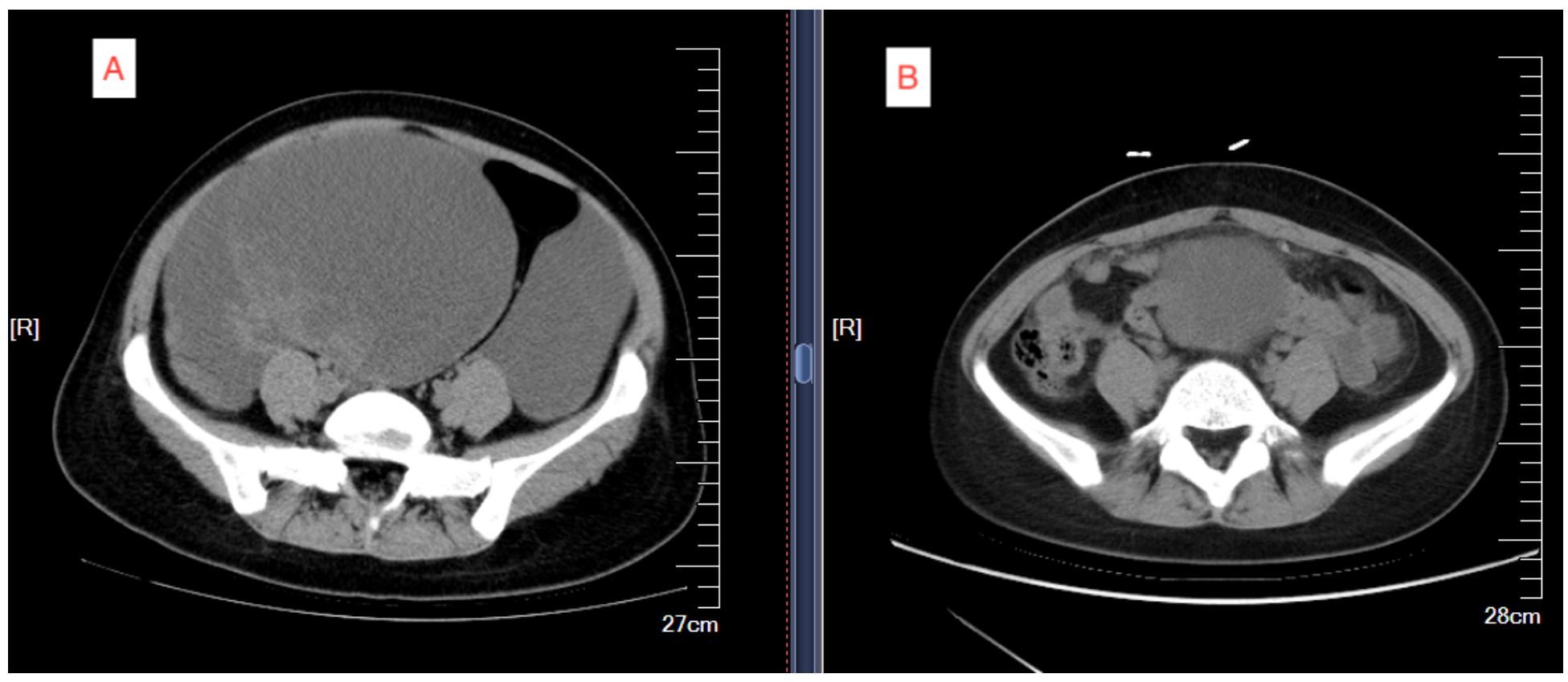

\section{Figure 1}

CT imaging findings of case 2. A \lmaging examination of CT suggests a huge mass in the right lower abdominal pelvic cavity. B: No obvious abnormalities were found during the review.

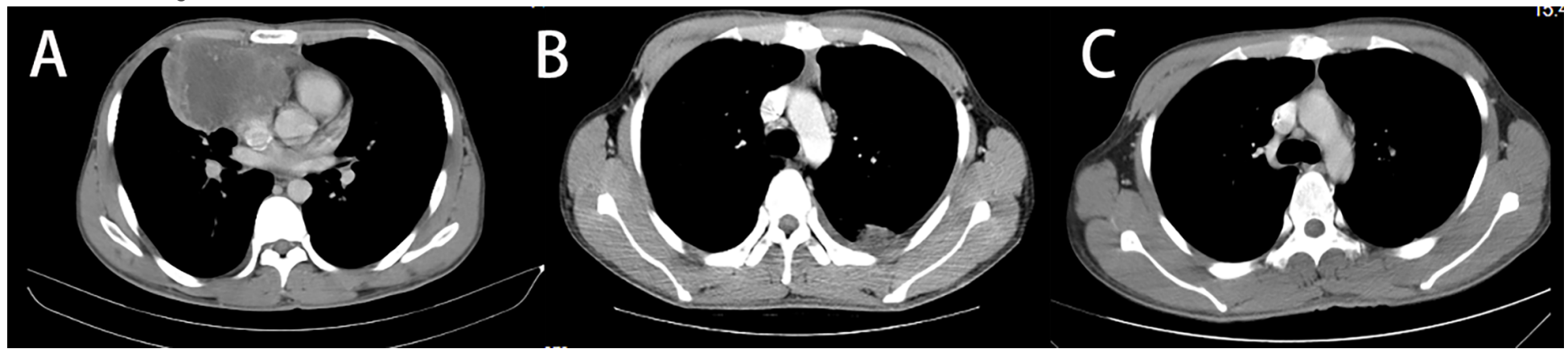

\section{Figure 2}

CT imaging findings of case 6. A: CT suggests an irregular anterior mediastinal mass. B: CT showed multiple nodules in pleura, considering the possibility of metastasis. C: No obvious abnormalities were found during the review. 